\title{
Grand Design Diplomasi Ekonomi Indonesia: Sebuah Pendekatan Indeks Diplomasi Ekonomi
}

\author{
Sulthon Sjahril Sabaruddin \\ Kementrian Luar Negeri Republik Indonesia \\ E-mail: Sulthon.sjahril@kemlu.go.id
}

\begin{abstract}
Abstrak
Studi ini mencoba menyusun sebuah blueprint diplomasi ekonomi Indonesia dengan merumuskan Indeks Diplomasi Ekonomi (IDE). Hasil IDE mengambarkan bahwa negara-negara sahabat dengan nilai IDE tertinggi dan masuk dalam kategori negara strategis yaitu Tiongkok, Singapura, Malaysia, Amerika Serikat, dan Jepang. Banyak negara-negara di pasar non-tradisional bagi Indonesia masuk dalam kategori negara strategis. Ditemukan beberapa negara mitra strategis bagi diplomasi ekonomi Indonesia seperti Mauritius, Republik Demokratik Kongo, Angola, Ghana, dan Uganda masih belum terdapat perwakilan Indonesia dan hubungan diplomatik dirangkap dari perwakilan Indonesia di negara sahabat lainnya. Sedangkan negara-negara kategori 'mitra biasa' seperti Laos, Bosnia Herzegovina, Fiji, Suriname, Vatikan, dan Noumea Pemerintah Indonesia justru menempatkan perwakilannya dengan pertimbangan politis dan sosial budaya seperti keterikatan sejarah seperti diaspora Indonesia.
\end{abstract}

Kata Kunci: indeks diplomasi ekonomi (IDE), diplomasi ekonomi Indonesia

Abstract

This studies try to arrange Indonesian economic diplomacy by conceive Economic Diplomacy Index (EDI). The result of (EDI) describes that countries with high EDI and included to strategic partnership are China, Singapore, Malaysia, United States of America, and Japan. Many countries in non-traditional markets for Indonesia included to strategic country category. There are several strategic partner country for Indonesian economic diplomacy like Mauritius, Democratic Republic of Congo, Angola, Ghana, Uganda are not exist Indonesian envoy and diplomatic relation have merged from Indonesian envoy in other partner countries. Meanwhile, category of common countries partner are Laos, Bosnia Herzegovina, Fiji, Suriname, Vatican, and Noumea. Indonesian government has placed its envoy by politic consideration and social cultural like history attachment like Indonesian diaspora.

Keywords: economic diplomacy index, Indonesian economic diplomacy

\section{Latar Belakang}

Sesuai visi dan misi program era Pemerintahan Joko Widodo (Jokowi) periode 2015-2019, salah satu program prioritas utama dalam kebijakan luar negeri adalah memperkuat kinerja diplomasi ekonomi Indonesia dengan tujuan untuk turut mendorong pertumbuhan ekonomi dan meningkatkan kesejahteraan masyarakat Indonesia. Untuk itu, di beberapa kesempatan Presiden Jokowi mengemukakan diplomat Indonesia harus menjadi 'salesperson' Indonesia di luar negeri dan tugas Duta Besar RI 
ke depan dititikberatkan pada diplomasi dagang ketimbang diplomasi politik. Guna mencapai tujuan tersebut, diplomat Indonesia dituntut untuk memahami benar kebutuhan di negara tujuan dan proaktif untuk memasarkan produk Indonesia untuk memenuhi permintaan negara tujuan tersebut. Namun demikian, dalam menjalankan diplomasi ekonomi Indonesia tentu terdapat berbagai tantangan baik dari lingkup domestik maupun global. Kondisi geoekonomi global merupakan salah satu tantangan sekaligus peluang bagi perekonomian Indonesia. Sedangkan, di lingkungan domestik, lemahnya infrastruktur dan daya saing ekspor masih merupakan tantangan besar Indonesia.

Dalam mendukung tujuan tersebut, Kementerian Luar Negeri (Kemlu) RI sebagai ujung tombak atau garda terdepan diplomasi Indonesia telah menekankan diplomasi ekonomi menjadi salah satu prioritas utama dalam kebijakan luar negeri Indonesia. Hal ini tertuang dalam Arah Kebijakan dan Strategi Renstra Kemlu Tahun 2015-2019, dimana penguatan diplomasi ekonomi merupakan salah satu dari 8 arah kebijakan yang disepakati. Selain Kemlu, instansi Pemerintah terkait lainnya seperti Kementerian Perdagangan, Kementerian Pariwisata, Kementerian Keuangan, Bank Indonesia dan Badan Koordinasi Penanaman Modal (BKPM) turut berperan penting dalam mendukung diplomasi ekonomi Indonesia.

Menlu RI, Retno L.P. Marsudi pada suatu kesempatan menjelaskan bahwa Kemlu RI memiliki tekad "Diplomasi untuk Rakyat, Diplomasi Membumi" dalam arti kinerja Kemlu tidak akan memiliki jarak dengan rakyat serta dapat dirasakan manfaatnya secara langsung oleh rakyat. Dalam membumikan diplomasi ekonomi, Menlu RI dalam pernyataan pers tanggal 29 Oktober 2014 menekankan setidaknya terdapat 4 pilar diplomasi ekonomi yakni: melakukan perluasan dan peningkatan akses pasar produk Indonesia dengan mendorong perubahan mindset para diplomat Indonesia agar lebih aktif melakukan diplomasi ekonomi bahkan terjun langsung di lapangan (blusukan); penguatan kapasitas dan sumber daya perwakilan RI di pasar non-tradisional, atau "untapped market";mendorong investasi asing pada sektor prioritas Indonesia, sebaliknya juga melindungi investasi Indonesia di luar negeri; serta pemanfaatan ASEAN Economic Community (AEC).

Salah satu aspek penting dari diplomasi ekonomi adalah meningkatkan kerjasama perdagangan, investasi dan pariwisata (Trade, Tourism, Investment / TTI). Adapun tujuan utama kerjasama TTI tersebut adalah mendorong ekspor Indonesia, meningkatkan investasi dan meningkatkan kunjungan wisatawan mancanegara, dalam rangka mendorong perekonomian nasional. Selain itu, TTI merupakan sumber devisa penting bagi perekonomian Indonesia dan sebagaimana diamanatkan dalam Rencana Pembangunan Jangka Menengah Nasional 2015-2019, Indonesia memiliki sasaran TTI yaitu: 
pertumbuhan ekspor produk non-migas rata-rata sebesar 11.6 persen per tahun; meningkatnya realisasi Penanaman Modal Asing (PMA) dan Penanaman Modal Dalam Negeri (PMDN) menjadi Rp. 933 triliun pada tahun 2019; serta meningkatnya jumlah kunjungan wisatawan mancanegara menjadi 20 juta orang pada tahun 2019. Dalam menjalankan kerjasama TTI,
Pemerintah Indonesia secara garis besar telah
memetakan negara-negara mitra baik dalam
pasar non-tradisional (pasar alternatif) maupun
pasar tradisional. Secara umum, pasar non-
tradisional merupakan negara-negara yang
potensial secara ekonomi dan prospektif sebagai
tujuan pasar seperti negara-negara di kawasan Amerika Latin, Eropa Tengah dan Timur, Afrika, Asia Tengah dan Pasifik Selatan. Sedangkan, pasar tradisional merupakan negara mitra Indonesia seperti Amerika Serikat (AS) dan Eropa Barat yang telah memiliki hubungan kerjasama ekonomi yang kuat sejak lama. Dalam implementasinya, negara-negara yang masuk dalam kategori pasar tradisional masih cukup lebih dominan dalam mendapat perhatian
Pemerintah Indonesia dibandingkan negaranegara di pasar non-tradisional. Hal ini dapat tercermin dari masih rendahnya frekuensi kunjungan Kepala Pemerintahan di negaranegara pasar non-tradisional. Selain itu, keseriusan Pemerintah dalam menggarap potensi pasar non-tradisional masih dianggap belum optimal. Padahal banyak negara-negara yang masuk dalam kategori pasar non-tradisional ini merupakan negara-negara potensial secara ekonomi maupun politis.

Namun jika ditelusuri selama periode 1989-2014, tergambarkan ilustrasi yang berbeda. Pangsa pasar perdagangan Indonesia di pasar tradisional di 10 mitra dagang utama menunjukkan tren penurunan yang cukup signifikan dari sebesar 73.85 persen (1989) menjadi 64.36 persen (2014). Sedangkan pangsa pasar perdagangan Indonesia di kawasan pasar non-tradisional mengalami peningkatan walaupun tidak signifikan. Pangsa pasar Indonesia di Amerika Latin pada tahun 1989 hanya sebesar 1.29 persen, dan kini pada tahun 2014 mencapai 2.375 persen. 
Tabel 1: Pangsa Pasar Indonesia di Pasar Tradisional Periode 1989-2014

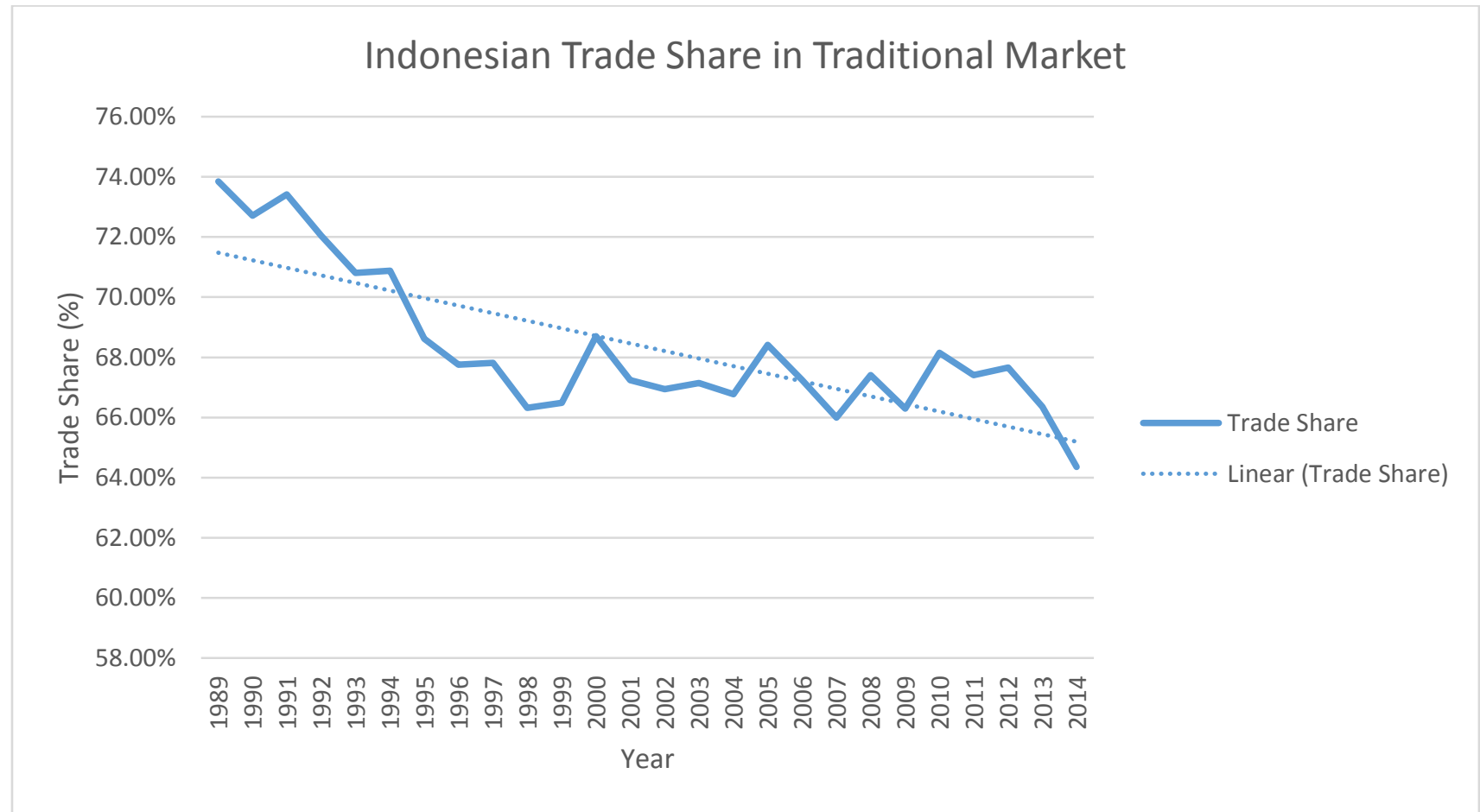

\section{Sumber: Diolah oleh Penulis}

Lebih lanjut, tren saat ini yang seringkali menjadi perhatian di banyak menggambarkan kerjasama hubungan ekonomi Selatan-Selatan dan antar negara-negara berkembang semakin meningkat khususnya sejak krisis ekonomi di AS dan Eropa Barat mulai tahun 2008. Dalam kaitan ini, Indonesia termasuk salah satu negara yang mencoba melakukan upaya untuk meningkatkan kerjasama ekonominya di pasar non-tradisional seperti Amerika Latin, Asia Tengah, Eropa Tengah dan Timur dan Afrika. Namun demikian upaya tersebut masih belum membuahkan hasil yang optimal. Salah satu alasan belum optimalnya pencapaian tersebut dikarenakan kalangan yakni belum terdapatnya sebuah blueprint atau grand design diplomasi ekonomi Indonesia sehingga saat ini arah dan pelaksanaan roda diplomasi ekonomi Indonesia serta negaranegara prioritas untuk kepentingan perekonomian dan diplomasi ekonomi Indonesia masih belum jelas dan terukur.

Tulisan ini mencoba untuk menjawab salah satu tantangan diplomasi ekonomi Indonesia saat ini yakni upaya penyusunan blueprint diplomasi ekonomi Indonesia. Dalam penyusunan blueprint diplomasi ekonomi Indonesia, penulis bermaksud untuk membentuk 
indeks diplomasi ekonomi Kemlu RI sehingga dapat mengetahui mana negara-negara yang sepatutnya menjadi prioritas diplomasi ekonomi Indonesia dan besaran alokasi sumber daya seperti anggaran dan personel yang dibutuhkan. Diharapkan terdapatnya indeks diplomasi ekonomi ini, ke depannya diplomasi ekonomi Kemlu RI dalam pelaksanaannya dapat lebih terarah, efisien, efektif dan tak kalah penting adalah terukur.

\section{Studi Pustaka dan Konsep Diplomasi Ekonomi}

Sejak berakhirnya perang dingin dan semakin menguatnya globalisasi ekonomi dunia, diplomasi ekonomi dengan tujuan untuk meningkatkan kesejahteraan masyarakat telah menjadi prioritas utama bagi banyak negara di berbagai belahan dunia (Bayne \& Woolcock, 2011). Walaupun isu politik dan keamanan sempat kembali menjadi perhatian besar setelah terjadinya serangan teroris 11 September 2001, namun diplomasi ekonomi kembali menjadi isu utama global setelah terjadinya krisis ekonomi dan keuangan dunia terutama di AS dan Eropa Barat pada tahun 2008, diikuti dengan resesi ekonomi yang berkelanjutan dan hingga saat ini masih belum pulih sepenuhnya.

Di era globalisasi saat ini, kondisi perekonomian suatu negara tidak dapat lepas dari perkembangan perekonomian dunia. Salah satu indikator untuk melihat kinerja dampak perekonomian luar negeri terhadap suatu negara tercermin melalui perkembangan neraca pembayaran. Neraca pembayaran sangat bermanfaat karena dapat menggambarkan struktur dan komposisi transaksi ekonomi dan posisi keuangan internasional suatu negara (Tambunan, 2001). Selain itu, neraca pembayaran merupakan salah satu indikator fundamental ekonomi suatu negara dan bahkan lembaga-lembaga keuangan internasional seperti Dana Moneter Internasional (IMF), Bank Dunia, dan negara-negara donor juga menggunakan neraca pembayaran sebagai salah satu indikator bahan pertimbangan dalam pemberian dana bantuan kepada suatu negara (Tambunan, 2001).

Neraca pembayaran merangkum seluruh hubungan ekonomi suatu negara di sektor luar negeri selama jangka waktu tertentu. Secara umum, kegiatan kerjasama ekonomi luar negeri mencakup: transaksi perdagangan yaitu kegiatan ekspor dan impor barang dan jasa; transaksi yang berhubungan dengan barang modal dan investasi yaitu penanaman modal langsung (foreign direct investment) dan investasi portofolio. Selain itu, terangkum pula transaksi lainnya seperti transaksi yang terkait pinjaman, penghasilan seperti pembayaran bunga dan pembagian dividen, serta transaksi yang terkait dengan transfer, seperti hibah dan remittance (pengiriman uang). Seluruh aliran dana dari kegiatan transaksi tersebut akan mempengaruhi jumlah cadangan devisa di suatu negara.

Sebagaimana disampaikan pada bab sebelumnya, Presiden Jokowi menargetkan untuk meningkatkan kinerja diplomasi ekonomi 
Indonesia dalam rangka mendorong pertumbuhan ekonomi dan meningkatkan pendapatan devisa nasional. Sasaran diplomasi ekonomi Indonesia yakni meningkatkan kinerja TTI tersebut terangkum dalam Rencana Pembangunan Jangka Menengah Nasional 20152019. Secara garis besar, target diplomasi ekonomi Indonesia dibawah kepemimpinan Presiden Jokowi ini mengambarkan salah satu teori pandangan ekonomi internasional klasik yaitu paradigma ekonomi merkantilis. Aliran merkantilisme pertama kali ditulis oleh Antinio Serra pada tahun 1613 dan dapat diartikan sebagai suatu paradigma dimana suatu negara memiliki pemahaman bahwa untuk meningkatkan kekuatan negaranya dapat dicapai dengan mengorbankan kekuatan negara pesaingnya (Perrotta, 2013). Dalam perdagangan internasional, suatu negara akan berupaya untuk mencapai neraca perdagangan surplus dengan mengekspor produk sebesar-besarnya dan membatasi impor dengan maksud untuk memperoleh devisa sebesar-besarnya yang merupakan salah satu tolak ukur kesejahteraan suatu negara (Basri \& Munandar, 2010). Maka, tergambarkan bahwa peran negara dalam meningkatkan pertumbuhan ekonomi dan kesejahteraan menjadi sangat dominan.

Dalam mencapai sasaran diplomasi ekonomi, di tengah tantangan persaingan global yang semakin ketat dan sulit ini, Pemerintah Indonesia harus mampu untuk memperkuat kemampuan serta mempertajam arah dan strategi diplomasi ekonomi Indonesia. Diplomasi ekonomi dapat didefinisikan sebagai upaya sistematis yang dijalankan suatu negara dengan memanfaatkan sejumlah kekuatan dan sumber daya ekonomi yang dimiliki seperti pemberlakuan sanksi atau pemberian rewards agar tercapai tujuan politik luar negerinya. Dalam hal ini, tujuan utama mendorong kinerja diplomasi ekonomi adalah demi tujuan kemajuan atau peningkatan pembangunan ekonomi nasional yang memang termaktub dalam salah satu tujuan politik luar negeri Indonesia saat ini pada Renstra Kementerian Luar Negeri 2015-2019. Dalam Renstra Kementerian Luar Negeri (2015), diplomasi ekonomi merupakan salah satu sasaran strategis Kementerian Luar Negeri dan didefinisikan sebagai pemanfaatan alat politik internasional untuk mencapai tujuan-tujuan ekonomi melalui berbagai kerja sama seperti pembangunan (termasuk kesehatan, pendidikan, dan pertanian), energi, lingkungan hidup, keuangan, dan pangan.

Menurut Aleksius Jemadu (2015), asumsi utama bagi para pendukung promosi diplomasi ekonomi adalah bahwa negara berkembang seperti Indonesia sepatutnya memprioritaskan kepentingan ekonomi daripada kepentingan politik karena dengan ekonomi yang kuat yang pada gilirannya mampu membiayai pertahanan dan keamanan yang kuat dan meningkatkan bargaining power serta tak kalah penting, relative power. Maka penguatan diplomasi ekonomi Indonesia dapat setidaknya menentukan tiga arah (dan tujuan) kebijakan 
luar negeri yaitu: penguatan diplomasi maritim dalam rangka menjaga kedaulatan Indonesia, peningkatan peran dan pengaruh Indonesia sebagai negara middle power di dunia internasional serta penguatan kepemimpinan Indonesia di ASEAN. Dari definisi ini tampak bahwa peningkatan kinerja TTI sudah selayaknya menjadi prioritas utama bagi Pemerintah Indonesia jika ingin mencapai tujuan tersebut.

Saat ini, Indonesia merupakan negara dengan kekuatan ekonomi terbesar di Asia Tenggara dan ketiga terbesar di Asia setelah Tiongkok dan India, dan masih memiliki potensi ekonomi yang sangat besar yang belum sepenuhnya dikelola secara optimal. Dilihat dari nilai Produk Domestik Bruto (harga berlaku), Indonesia merupakan ekonomi ke-16 terbesar di dunia dan merupakan salah satu anggota Group 20 (G20). Lebih lanjut, Indonesia memiliki banyak kekuatan dan potensi ekonomi seperti sumber daya alam dan bonus demografi (surplus pekerja usia produktif) yang jika dikekola dan dioptimalkan dengan baik dapat membantu mendorong pertumbuhan ekonomi dan memperkuat perekonomian nasional di masa mendatang. PricewaterhouseCoopers (2015) bahkan memprediksi Indonesia akan menjadi negara ke-4 perekonomian terbesar dunia pada tahun 2050. Namun upaya untuk mencapai target tersebut tentu tidak terlepas dari berbagai tantangan yang ada saat ini dan di masa mendatang.
Studi ini mencoba untuk merumuskan sebuah Indeks Diplomasi Ekonomi (IDE) Kementerian Luar Negeri RI dan diharapkan indeks ini dapat menjadi salah satu rujukan setidaknya dalam menentukan negara-negara prioritas untuk kepentingan perekonomian dan diplomasi ekonomi nasional yang dimana banyak yang berpandangan bahwa hingga saat ini penentuan prioritas negara-negara bagi diplomasi ekonomi Indonesia masih belum jelas serta tidak terukur. Dirumuskannya IDE diharapkan dapat menjadi titik awal dalam menjawab tantangan dimaksud sehingga pada akhirnya diplomasi ekonomi dapat terlaksana dengan lebih efektif, terarah, dan fokus. Selain itu, IDE ini dapat menjadi salah satu masukan dan rujukan dalam mendesain suatu blueprint atau grand design diplomasi ekonomi Indonesia ke depannya.

Dalam menyusun IDE, studi ini memanfaatkan variabel sasaran diplomasi ekonomi Indonesia yaitu ekspor, Penanaman Modal Asing (PMA), wisatawan mancanegara (wisman), serta transfer penghasilan (remittances) yang seluruhnya merupakan sumber devisa negara. Pendapatan sumber devisa negara ini penting dalam upaya Pemerintah untuk meningkatkan kesejahteraan negara. Sebagaimana diamanatkan dalam Pembukaan UUD 1945, salah satu tujuan utama dari dibentuknya Negara Kesatuan Republik Indonesia (NKRI) adalah memajukan kesejahteraan umum dan mencerdaskan kehidupan bangsa. Tujuan ini dimaksud agar 
kemakmuran dan kecerdasan dapat terus berkembang sehingga ke depan Indonesia dapat menjadi negara yang makmur dan maju (Ismail et al, 2014). Selain itu, akan dimanfaatkan pula dua indikator sosio-ekonomi yaitu jumlah populasi dan nilai Produk Domestik Bruto (PDB) dari negara-negara mitra untuk mengukur potensi pasar dari negara-negara mitra. Kedua indikator ini dianggap sangat penting untuk mengukur kekuatan ekonomi sekaligus potensi pasar negara-negara sahabat bagi diplomasi ekonomi Indonesia.

Setelah diperoleh angka IDE tersebut, selanjutnya akan dilakukan ranking dan cluster negara-negara tujuan diplomasi ekonomi Indonesia sehingga dapat tergambarkan negaranegara yang seharusnya menjadi prioritas diplomasi ekonomi Indonesia saat ini dan kedepannya. Adapun cluster negara-negara sahabat akan merujuk definisi kategorisasi Kajian Mandiri Pusat Pengkajian dan Pengembangan Kebijakan Kawasan Amerika dan Eropa (Pusat P2K2 Amerop) pada tahun 2013 yang dibagi menjadi tiga klasifikasi: negara strategis, negara penting, dan negara mitra. Namun definisi dan klasifikasi ini disesuaikan dan dimodifikasikan hanya berdasarkan pertimbangan tujuan diplomasi ekonomi semata ${ }^{1}$. Adapun definisi masing-

1 Kajian Mandiri Pusat P2K2 Amerop (2013) menjelaskan kategorisasi status hubungan Indonesia dengan negara-negara sahabat dilihat berdasarkan kontribusi hubungannya atas pencapaian prioritas hubungan luar negeri Indonesia yaitu: penguatan kerjasama ASEAN dan regional di Asia Timur, masing status (atau kategorisasi) hubungan negara-negara sahabat adalah sebagai berikut:

1. Strategis, yang berarti hubungan memegang peranan kunci bagi pencapaian tujuan hubungan luar negeri.

2. Penting, yang berarti hubungan memainkan peranan penting namun bukan kunci dalam pencapaian tujuan hubungan luar negeri.

3. Kemitraan (atau mitra), yang berarti hubungan berperan minimal atau bahkan tidak ada sama sekali dalam pencapaian tujuan prioritas hubungan luar negeri.

Dalam penyusunan IDE, adapun penjelasan terkait definisi dan pentingnya penggunaan variabel sasaran diplomasi ekonomi Indonesia dan indikator sosio-ekonomi tersebut adalah sebagai berikut: pertama, ekspor merupakan salah satu variabel dalam perdagangan internasional dan variabel ini penting sebagai salah satu cara untuk mendorong pertumbuhan ekonomi nasional dan sebagai salah satu sumber devisa negara. Nilai atau volume barang yang keluar atau ekspor suatu negara tercatat dalam neraca perdagangan. Jika ekspor lebih besar daripada impor, maka

mewujudkan stabilitas keamanan dan perdamaian di kawasan Asia Pasifik, dan meningkatkan kesejahteraan masyarakat dan pertumbuhan ekonomi melalui penguatan diplomasi ekonomi, khususnya melalui peningkatan dagang dan ekspansi pasar tujuan ekspor produk-produk Indonesia dan menarik investasi asing. 
saldo neraca perdagangan positif (surplus), dan sebaliknya jika impor lebih besar daripada ekspor, maka saldo neraca perdagangan menjadi defisit. Namun perlu dicatat bahwa kinerja ekspor tidak hanya diukur dari nilai atau volume ekspor saja, akan tetapi harus dilihat pula dari tingkat diversifikasinya, baik dalam arti variasi produk (pendalaman struktur ekonomi) maupun diversifikasi pasar negara tujuan ekspor atau perluasan jenis-jenis komoditas ekspor dan pasarnya (Tambunan, 2001).

Dalam mendorong kinerja ekspor nasional, promosi perdagangan seperti melalui penyelengaraan dan partisipasi dalam pameran dan misi dagang internasional merupakan salah satu upaya penting dalam mendukung diplomasi ekonomi Indonesia. Pameran dan misi dagang internasional dapat dilakukan di dalam negeri maupun di luar negeri dengan melibatkan berbagai stakeholders terkait. Saat ini, Pemerintah Indonesia memiliki 133 Perwakilan RI di luar negeri ${ }^{2}$, atase perdagangan di 24 kota besar dunia dan Indonesian Trade Promotion Center (ITPC) di 19 kota perdagangan dunia untuk turut mendukung pelaksanaan diplomasi ekonomi Indonesia (Badan Pengkajian dan Pengembangan Kebijakan, 2014).

\footnotetext{
${ }^{2}$ Perwakilan RI diluar negeri mencakup Kedutaan Besar Republik Indonesia (KBRI), Konsulat Jenderal Republik Indonesia (KJRI), Konsulat Republik Indonesia (KRI), dan Perwakilan Tetap Republik Indonesia (PTRI). Selain itu, terdapat pula Konsul Kehormatan di sejumlah negara-negara sahabat dalam rangka memperkuat hubungan kerjasama seperti dalam bidang ekonomi dan sosial-budaya.
}

Selain itu, Pemerintah Indonesia juga telah menjalankan serangkaian upaya diplomasi ekonomi seperti pembukaan akses pasar serta meningkatkan daya saing dengan mengoptimalkan peran instrumen perdagangan yang ada (FTA, GSP, trade agreement). Namun hasil upaya meningkatkan kinerja ekspor Indonesia dimaksud masih belum optimal. Selama beberapa tahun terakhir nilai ekspor Indonesia mengalami tren penurunan yang cukup besar. Pada tahun 2011, nilai ekspor Indonesia mencapai US\$203 milyar dan kini pada tahun 2014 menurun menjadi US\$176 milyar. Penurunan kinerja ekspor tidak hanya akibat dari ketidakpastian perekonomian global saat ini, tetapi sejumlah permasalahan dalam negeri seperti masih lemahnya daya saing ekspor perekonomian nasional dan kurang efektifnya kinerja koordinasi diplomasi ekonomi antar Kementerian dan Lembaga Pemerintah terkait dengan termasuk stakeholders terkait masih menjadi kendala besar dalam meningkatkan kinerja diplomasi ekonomi (dalam hal ini kinerja ekspor Indonesia).

Tabel 2: Nilai Ekspor Indonesia Selama

Periode 2011-2014 (Dalam Milyar US\$)

\begin{tabular}{|c|c|c|}
\hline $\mathbf{2 0 1 2}$ & $\mathbf{2 0 1 3}$ & $\mathbf{2 0 1 4}$ \\
\hline 190.02 & 182.55 & 176.29 \\
\hline
\end{tabular}

Sumber: Kementerian Perdagangan Republik Indonesia (2015)

Kedua, investasi asing (PMA) merupakan salah satu variabel penting dalam mendukung roda perekonomian nasional. PMA 
merupakan investasi langsung yang berasal dari luar negeri, ataupun dana yang berasal dari para investor luar negeri yang ditanamkan di suatu negara (Fahmi, 2010). Pada negara berkembang (developing countries) dan terbelakang (least developed countries), kebijakan menarik investasi asing menjadi salah satu agenda diplomasi ekonomi yang digalakkan. Sebagaimana tujuan diplomasi ekonomi di banyak negara-negara berkembang lain pada umumnya, Indonesia juga memiliki kepentingan ekonomi untuk menarik investasi asing sebanyak-banyaknya ke dalam negeri dengan tujuan untuk memperoleh devisa negara dan mendukung perekonomian nasional. Cukup banyak manfaat yang bisa diperoleh dalam PMA ini. Selain untuk membuka lapangan kerja dan memberikan kontribusi devisa bagi negara, melalui PMA diharapkan dapat terjadinya alih teknologi dan alih konsep manajemen.

Sebagai gambaran, pada tahun 2012 nilai investasi asing di Indonesia mencapai US\$19.1 milyar dan kini pada tahun 2014 meningkat menjadi US\$22.6 milyar. Potensi untuk meningkatkan nilai investasi asing masih cukup besar. Menurut The Economist Corporate Network - Asia Business Outlook 2015, Indonesia masih merupakan destinasi penanaman modal yang menarik dan relatif aman dan berdasarkan hasil survei, Indonesia merupakan negara prioritas tujuan penanaman modal kedua setelah Tiongkok, dan mengungguli negara-negara potensial seperti India, Malaysia dan Vietnam (Wardhana, 2015).
Tabel 3: Nilai Investasi Asing di Indonesia Selama Periode 2012-2014 (Dalam Milyar US\$)

\begin{tabular}{|c|c|c|}
\hline 2012 & 2013 & 2014 \\
\hline 19.1 & 18.8 & 22.6 \\
\hline
\end{tabular}

Sumber: World Investment Report UNCTAD

(2013-2015)

Dalam upaya menarik investasi asing, beberapa upaya Pemerintah yang dijalankan antara lain: meningkatkan kegiatan promosi TTI termasuk penguatan image building dan promosi yang lebih fokus (targeted promotion); melakukan kajian market intelligence; serta melalui sejumlah kebijakan seperti memberikan sejumlah insentif atau kemudahan-kemudahan penanaman investasi asing, seperti tax holiday, insentif, penghilangan bea masuk, dan lainnya (Badan Pengkajian dan Pengembangan Kebijakan, 2014). Selain itu, Pemerintah Indonesia telah membuka Indonesia Investment Promotion Centre (IIPC) di 8 negara besar yang merupakan investor utama bagi Indonesia. Secara teknis, promosi investasi Indonesia di luar negeri lebih banyak dipusatkan kepada negara-negara investor utama, namun Badan Koordinasi Penanaman Modal (BKPM) juga tetap melakukan promosi di sejumlah negara lainnya yang dipandang potensial. Mengingat prioritas dan keterbatasan biaya promosi yang tersedia, intensitas kegiatan promosi masih relatif sedikit dilaksanakan di negara-negara selain negara utama. 
Ketiga, jumlah kunjungan wisman merupakan salah satu variabel yang semakin penting sebagai sumber penghasil devisa negara. Salah satu dari berbagai upaya untuk meningkatkan jumlah kunjungan wisman adalah kebijakan pembebasan visa kunjungan ke Indonesia. Pada tahap pertama, Indonesia telah membebaskan visa kunjungan untuk 30 negara per 9 Juni 2015, di luar 15 negara ASEAN dan mitra utamanya yang sudah lebih dulu memperoleh bebas visa kunjungan ke Indonesia. Pada tahap kedua, diusulkan akan terdapat 47 negara tambahan bebas visa kunjungan ke Indonesia efektif Oktober 2015, sehingga total bebas visa kunjungan yang diberikan mencapai 92 negara (Putra, 2015). Kebijakan pembebasan visa kunjungan diharapkan dapat meningkatkan devisa nasional melalui peningkatan jumlah kunjungan wisman.

Berbagai upaya kegiatan promosi internasional telah dijalankan oleh Pemerintah Indonesia untuk menarik wisatawan asing. Kegiatan promosi selama ini dilaksanakan melalui kegiatan-kegiatan antara lain bursa pariwisata untuk mempertemukan penjual dan pembeli, Sales Mission, Festival Indonesia, Familiarization Trips (Famtrip), dan Direct Selling at Malls (Badan Pengkajian dan Pengembangan Kebijakan, 2014).Guna mendukung kegiatan promosi pariwisata Indonesia diluar negeri, Pemerintah Indonesia telah membuka 15 kantor Visit Indonesia Tourism Officer (VITO) di negara-negara prioritas target pariwisata Indonesia. Sebagai gambaran, pada tahun 2013 jumlah kunjungan wisman di Indonesia mencapai 8.8 juta orang dan pada tahun berikutnya meningkat menjadi 9.4 juta orang. Sektor pariwisata Indonesia harus bisa dimanfaatkan secara optimal untuk memperkuat perekonomian nasional serta meningkatkan sumber devisa negara.

\section{Tabel 4: Jumlah Kunjungan Wisatawan}

Mancanegara ke Indonesia

Selama Periode 2012-2014

\begin{tabular}{|c|c|c|}
\hline 2012 & 2013 & 2014 \\
\hline 8.04 juta & 8.8 juta & 9.43 juta \\
\hline
\end{tabular}

Sumber: Badan Pusat Statistik Republik Indonesia (2015)

Keempat, remittances (transfer penghasilan) merupakan salah satu variabel penting dalam meningkatkan sumber penghasil devisa negara. Kontribusi transfer penghasilan terhadap perekonomian Indonesia cukup besar. Banyak Tenaga Kerja Indonesia (TKI) yang bekerja diluar negeri dan memperoleh pendapatan di negara penerima (host) dan kemudian melakukan transfer pendapatan ke negara asal (remittances). Selama beberapa tahun terakhir, jumlah remitansi mengalami peningkatan. Pada tahun 2012, jumlah remitansi sebesar US\$7.01 milyar dan kini pada tahun 2014 menjadi US\$8.34 milyar. Besarnya jumlah remitansi ini dalam mendukung perekonomian nasional membuat TKI sering dijuluki sebagai pahlawan devisa nasional.

\section{Tabel 5: Jumlah Remitansi ke Indonesia} Selama Periode 2012-2014 


\begin{tabular}{|c|c|c|}
\hline 2012 & 2013 & 2014 \\
\hline 7.01 milyar & 7.41 milyar & 8.34milyar \\
\hline
\end{tabular}

Sumber: Bank Indonesia (2015)

Selain keempat indikator variabel sasaran diplomasi ekonomi diatas, pada IDE akan menggunakan dua indikator sosio-ekonomi yaitu jumlah populasi dan nilai PDB dari negaranegara mitra untuk mengukur potensi pasar dari negara-negara mitra.PDB secara umum dapat digunakan sebagai indikator kinerja perekonomian suatu negara dan sebagai salah satu tolok ukur kesejahteraan masyarakat. Sedangkan indikator jumlah populasi menggambarkan besarnya potensi konsumen di suatu perekonomian. Pemanfaatan kedua indikator ini menjadi tolok ukur potensi pasar dan dianggap penting sebagai pertimbangan dalam diplomasi ekonomi Indonesia mengingat kedua variabel sosio-ekonomi tersebut menggambarkanpotensi dan daya beli konsumen di negara-negara sahabat untuk tujuan ekspor produk Indonesia.

\section{Metodologi Penelitian}

Mengapa Pemerintah Indonesia memerlukan IDE? Pertama, IDE dibutuhkan untuk memberikan sinyal kemana sepatutnya diplomasi ekonomi diarahkan. Siapa pun yang berkepentingan dengan pengambilan keputusan akan membutuhkan informasi yang dapat menentukan arah dan prioritas kebijakan dalam hal kebijakan dalam diplomasi ekonomi. Kedua, hingga saat ini masih belum terdapat suatu tolok ukur yang jelas dalam menentukan negara- negara yang seharusnya menjadi prioritas diplomasi ekonomi Indonesia. Berdasarkan alasan tersebut serta mengingat diplomasi ekonomi menjadi salah satu prioritas dalam politik luar negeri di era Pemerintahan Jokowi, maka penyusunan IDE diperlukan setidaknya untuk keperluan di lingkungan Kemlu yang merupakan garda terdepan diplomasi Indonesia dalam memperkuat diplomasi ekonomi Indonesia.

Dalam penyusunan IDE, studi ini akan memanfaatkan variabel sasaran diplomasi ekonomi Indonesia yaitu ekspor Indonesia ke negara tujuan, Penanaman Modal Asing (PMA) di Indonesia, jumlah kunjungan wisatawan mancanegara (wisman), serta transfer penghasilan (remittances) dari negara host yang seluruhnya merupakan sumber devisa negara. Selain itu, akan dimanfaatkan pula dua indikator sosio-ekonomi yaitu jumlah populasi dan nilai PDB dari negara-negara mitra untuk mengukur potensi pasar dari negara-negara mitra. Seluruh indikator ini dipilih akan menjadi masukan dalam membentuk IDE.

RPJMN 2015-2019, menekankan pentingnya meningkatkan ekspor Indonesia, menarik investasi asing dan wisman asing sebesar-besarnya untuk meningkatkan devisa negara. Dalam RPJMN tidak disampaikan prioritas dari ke-tiga variabel ekonomi tersebut. Mengingat sasaran diplomasi ekonomi dalam RPJMN 2015-2019 tidak mencantumkan skala prioritas dan bobot, serta belum terdapatnya pula 
landasan teori dalam penyusunan IDE, maka dalam studi ini diasumsikan memiliki prioritas yang sama. Begitu pula dengan indikator potensi pasar, yakni Produk Domestik Bruto (PDB) dan populasi negara mitra juga diasumsikan memiliki bobot yang sama. Maka dari itu, pendekatan indeks yang akan digunakan dalam menyusun IDE adalah metode bobot timbangan sama (equally weighted) dengan metode agregatif sederhana. Karena semua variabel diasumsikan sama penting, maka pendekatan penghitungan IDE dapat disebut pula metode angka indeks tidak tertimbang yaitu metode yang tidak menggunakan faktor penimbang dalam menghitung suatu indeks.

Tabel 6: Metode Angka Indeks Tidak Tertimbang

\begin{tabular}{|l|l|l|}
\hline Angka Indeks Relatif & $\begin{array}{l}\text { Angka Indeks Agregatif } \\
\text { Sederhana }\end{array}$ & $\begin{array}{l}\text { Angka Indeks Rata-Rata Relatif } \\
\text { Sederhana }\end{array}$ \\
\hline$P_{o / n}=\frac{P_{n}}{P_{0}} \times 100$ & $P_{o / n}=\frac{\sum P_{n}}{\sum P_{o}} \times 100$ & Rata-Rata Hitung \\
$Q_{o / n}=\frac{Q_{n}}{Q_{0}} \times 100$ & $Q_{o / n}=\frac{\sum Q_{n}}{\sum Q_{o}} \times 100$ & Rata-Rata Ukur $\frac{P_{n} \times 100}{P_{o}}$ \\
\hline$V_{o / n}=\frac{P_{n} \cdot Q_{n}}{P_{0} \cdot Q_{0}} \times 100$ & $V_{o / n}=\frac{\sum P_{n} \cdot Q_{n}}{\sum P_{o} \cdot Q_{o}} \times 100$ & LogIRH $=\frac{\sum \log \frac{P_{n}}{P_{o}} \times 100}{\sum k}$ \\
\hline
\end{tabular}

\section{Sumber: Saleh (1986)}

Pendekatan ini dapat dikatakan salah satu pendekatan yang paling sederhana dalam penyusunan sebuah indeks, namun masih terdapat beberapa kelemahan dalam metode ini. Kelebihan model ini bersifat sederhana dan mudah cara penghitungannya. Namun terdapat beberapa kelemahan dari model ini seperti: setiap variabel mempunyai bobot yang sama, meskipun mungkin besar pengaruhnya berbeda; serta dipengaruhi oleh satuan, dan bila satuan berubah, maka akan mempengaruhi ukuran indeks.

Setelah diolah dan diperoleh hasil IDE Indonesia dengan seluruh negara-negara mitra, penulis akan melakukan ranking seluruh negara berdasarkan prioritas dan mengkategorisasikan 
seluruh negara berdasarkan status hubungannya dengan pendekatan yang telah dirangkum dalam Kajian Mandiri Pusat Pengkajian dan Pengembangan Kebijakan Kawasan Amerika dan Eropa Kemlu RI (2013). Adapun tiga kategorisasi status hubungan Indonesia dengan negara-negara sahabat adalah sebagai berikut:

1. Strategis, yang berarti hubungan memegang peranan kunci bagi pencapaian tujuan hubungan luar negeri.

2. Penting, yang berarti hubungan memainkan peranan penting namun bukan kunci dalam pencapaian tujuan hubungan luar negeri.

3. Kemitraan (mitra biasa), yang berarti hubungan berperan minimal atau bahkan tidak ada sama sekali dalam pencapaian tujuan prioritas hubungan luar negeri.

Dalam kategorisasi status hubungan Indonesia tersebut disusun berdasarkan pertimbangan kontribusi hubungan tersebut atas pencapaian prioritas hubungan luar negeri RI. Dalam studi ini akan dimodifikasi menjadi sesuai dengan tujuan sasaran diplomasi ekonomi dan pertimbangan potensi pasar di negara-negara sahabat. Adapun pendekatan kategorisasi status hubungan Indonesia dengan negara-negara sahabat dengan metode timbangan sama (equally weighted). Dalam studi ini, penulis telah melakukan pengumpulan data melalui studi pustaka dan melakukan kunjungan ke Kementerian/Lembaga terkait di Indonesia yang berperan strategis dalam pelaksanaan diplomasi ekonomi, seperti Kementerian Perdagangan, Kementerian Pariwisata, Badan Koordinasi Penanaman Modal, Kementerian Luar Negeri dan Bank Indonesia khususnya untuk memperoleh masukkan indikator ekonomi yang lebih komprehensif dalam penyusunan IDE.

\section{Pembahasan Hasil}

Sebagaimana dijelaskan pada bab sebelumnya, hasil IDE 2014 menjelaskan seberapa penting negara sahabat Indonesia bagi diplomasi ekonomi Indonesia. Tergambarkan bahwa nilai IDE tertinggi yaitu: Tiongkok sebesar 52.807 poin, diikuti Singapura (47.752 poin), Malaysia (44.599 poin), Amerika Serikat (40.745 poin), dan Jepang (31.366 poin). Cukup banyak negara-negara di pasar non-tradisional yang sepatutnya menyandang sebagai 'negara strategis'. Di kawasan Amerika Latin, terdapat negara-negara yang cukup potensial seperti Brazil, Meksiko, Argentina, Kolombia, Venezuela, Peru, dan Cili masuk dalam kategori negara-negara strategis bagi kepentingan diplomasi ekonomi Indonesia. Sedangkan di kawasan Eropa Tengah dan Timur negaranegara seperti Turki, Polandia, Ukraina, dan Rumania masuk dalam daftar negara-negara strategis bagi Indonesia.

Di kawasan Asia, negara-negara besar Asia Timur seperti Singapura, Malaysia, Jepang, 
Korea Selatan, Thailand, dan Filipina masuk dalam negara mitra strategis papan atas. Selain itu, terdapat pula negara-negara dari kawasan Timur Tengah dan Asia Selatan seperti India, Arab Saudi, Persatuan Emirat Arab, Pakistan, Bangladesh, dan Iran yang turut masuk dalam kategori negara-negara mitra strategis. Sedangkan untuk kawasan Afrika, negara-negara seperti Nigeria, Mesir, Mauritius, Ethiopia, dan Republik Demokratik Kongo turut masuk dalam daftar negara-negara strategis bagi kepentingan diplomasi ekonomi Indonesia. Hal yang menarik adalah dengan negara sahabat kategori mitra strategis, hingga kini Indonesia masih belum menempatkan perwakilannya di negara-negara seperti Mauritius, Republik Demokratik Kongo, Angola, Ghana, dan Uganda. Hubungan diplomatik Indonesia dengan negara-negara tersebut masih dirangkap dari perwakilan Indonesia di negara sahabat lainnya.

\begin{tabular}{|c|c|c|c|c|c|}
\hline Ranking & Negara & $\begin{array}{l}\text { Nilai } \\
\text { IDE }\end{array}$ & Ranking & Negara & $\begin{array}{l}\text { Nilai } \\
\text { IDE }\end{array}$ \\
\hline 1 & Tiongkok & 52.807 & 33 & Polandia & 1.286 \\
\hline 2 & Singapura & 47.752 & 34 & Ethiopia & 1.266 \\
\hline 3 & Malaysia & 44.599 & 35 & Argentina & 1.198 \\
\hline 4 & Amerika Serikat & 40.745 & 36 & Myanmar & 1.127 \\
\hline 5 & Jepang & 31.366 & 37 & Kolombia & 1.065 \\
\hline 6 & India & 26.397 & 38 & Ukraina & 0.940 \\
\hline 7 & Australia & 19.612 & 39 & Yordania & 0.901 \\
\hline 8 & Arab Saudi & 17.502 & 40 & $\begin{array}{c}\text { Kongo, Republik } \\
\text { Demokratik }\end{array}$ & 0.898 \\
\hline 9 & Korea Selatan & 12.829 & 41 & Venezuela & 0.893 \\
\hline 10 & Inggris & 9.399 & 42 & Brunei Darussalam & 0.844 \\
\hline 11 & Belanda & 9.005 & 43 & Qatar & 0.828 \\
\hline 12 & Jerman & 6.973 & 44 & Aljazair & 0.821 \\
\hline 13 & Thailand & 6.257 & 45 & Tanzania & 0.814 \\
\hline 14 & Brazil & 5.793 & 46 & Swedia & 0.797 \\
\hline 15 & Perancis & 4.870 & 47 & Kenya & 0.758 \\
\hline 16 & Italia & 4.843 & 48 & Peru & 0.722 \\
\hline 17 & Filipina & 4.332 & 49 & Irak & 0.683 \\
\hline 18 & Rusia & 4.307 & 50 & Oman & 0.661 \\
\hline
\end{tabular}




\begin{tabular}{|c|c|c|c|c|c|}
\hline 19 & $\begin{array}{c}\text { Persatuan Emirat } \\
\text { Arab }\end{array}$ & 4.209 & 51 & Swiss & 0.628 \\
\hline 20 & Pakistan & 3.979 & 52 & Sudan & 0.605 \\
\hline 21 & Spanyol & 3.462 & 53 & Sri Lanka & 0.602 \\
\hline 22 & Meksiko & 3.353 & 54 & Cili & 0.592 \\
\hline 23 & Nigeria & 3.194 & 55 & Norwegia & 0.589 \\
\hline 24 & Kanada & 3.158 & 56 & Afghanistan & 0.579 \\
\hline 25 & Bangladesh & 3.097 & 57 & Maroko & 0.572 \\
\hline 26 & Vietnam & 3.054 & 58 & Denmark & 0.564 \\
\hline 27 & Turki & 2.917 & 59 & Austria & 0.556 \\
\hline 28 & Afrika Selatan & 2.276 & 60 & Angola & 0.533 \\
\hline 29 & Mesir & 2.272 & 61 & Romania & 0.517 \\
\hline 30 & Iran & 1.651 & 62 & Ghana & 0.513 \\
\hline 31 & Mauritius & 1.617 & 63 & Uganda & 0.507 \\
\hline 32 & Belgia & 1.564 & & & \\
\hline
\end{tabular}

Tabel 7: Negara Sahabat Kategori Strategis Berdasarkan Indeks Diplomasi Ekonomi Tahun 2014 Sumber: Diolah oleh Penulis

Pada kategori negara sahabat 'penting', pada tahun 2014 hasil IDE menemukan bahwa 5 negara kategori penting teratas adalah: Kamboja (0.504 poin), Yunani (0.475 poin), Portugal (0.464 poin), Selandia Baru (0.453 poin), dan Uzbekistan (0.442 poin). Di kawasan Eropa, negara-negara Eropa Barat seperti Yunani, Portugal, Irlandia, dan Luksemburg masuk dalam negara sahabat 'penting'. Sedangkan di kawasan Eropa Tengah dan Timur, terdapat negara-negara seperti Ceko, Hongaria, Belarus, Slovakia, Serbia, Slovenia, Kroasia dan Georgia yang masuk dalam kategori negara penting bagi diplomasi ekonomi Indonesia.
Di kawasan Amerika Latin, sejumlah negara masuk dalam kategori ini seperti Ekuador, Guatemala, Bolivia, Panama, Kuba, Paraguay, Uruguay, Kosta Rika dan Honduras. Selanjutnya, di kawasan Afrika, negara-negara seperti Pantai Gading, Mozambik, Madagaskar, Kamerun dan Senegal masuk dalam kategori negara 'penting'. Sedangkan di kawasan Asia Tenggara, Kamboja dan Timor Leste masuk dalam kategori ini. Untuk kawasan Arab, terdapat negara-negara seperti Yaman dan Kuwait masuk dalam kategori negara mitra penting bagi diplomasi ekonomi Indonesia. 
Tabel 8: Negara Sahabat Kategori Penting Berdasarkan Indeks Diplomasi Ekonomi

Tahun 2014

\begin{tabular}{|c|c|c|c|c|c|}
\hline Ranking & Negara & $\begin{array}{l}\text { Nilai } \\
\text { IDE }\end{array}$ & Ranking & Negara & Nilai IDE \\
\hline 1 & Kamboja & 0.504 & 33 & Mali & 0.210 \\
\hline 2 & Yunani & 0.475 & 34 & $\begin{array}{l}\text { Papua } \\
\text { Nugini }\end{array}$ & 0.206 \\
\hline 3 & Portugal & 0.464 & 35 & Haiti & 0.198 \\
\hline 4 & Selandia Baru & 0.453 & 36 & Bulgaria & 0.197 \\
\hline 5 & Uzbekistan & 0.442 & 37 & Tunisia & 0.194 \\
\hline 6 & Mozambik & 0.422 & 38 & Zimbabwe & 0.193 \\
\hline 7 & Kazakhstan & 0.420 & 39 & Azerbaijan & 0.192 \\
\hline 8 & Yaman & 0.417 & 40 & Belarus & 0.191 \\
\hline 9 & Finlandia & 0.416 & 41 & Guinea & 0.188 \\
\hline 10 & Kuwait & 0.410 & 42 & Togo & 0.186 \\
\hline 11 & Ceko & 0.387 & 43 & Timor Leste & 0.179 \\
\hline 12 & Nepal & 0.375 & 44 & Chad & 0.176 \\
\hline 13 & Pantai Gading & 0.362 & 45 & Slovakia & 0.174 \\
\hline 14 & Ekuador & 0.357 & 46 & Bolivia & 0.171 \\
\hline 15 & Seychelles & 0.345 & 47 & Panama & 0.171 \\
\hline 16 & Irlandia & 0.343 & 48 & Somalia & 0.159 \\
\hline 17 & Madagaskar & 0.340 & 49 & Rwanda & 0.157 \\
\hline 18 & Kamerun & 0.336 & 50 & Lebanon & 0.155 \\
\hline 19 & Suriah & 0.318 & 51 & Libya & 0.142 \\
\hline 20 & Hongaria & 0.316 & 52 & Kuba & 0.140 \\
\hline 21 & Korea Utara & 0.307 & 53 & Serbia & 0.133 \\
\hline 22 & Benin & 0.291 & 54 & Slovenia & 0.132 \\
\hline 23 & Guatemala & 0.275 & 55 & Burundi & 0.131 \\
\hline 24 & Luksemburg & 0.261 & 56 & Mauritania & 0.130 \\
\hline 25 & Bahrain & 0.251 & 57 & Paraguay & 0.128 \\
\hline 26 & Senegal & 0.246 & 58 & Uruguay & 0.127 \\
\hline
\end{tabular}




\begin{tabular}{|c|c|c|c|c|c|}
\hline 27 & Niger & 0.245 & $\mathbf{5 9}$ & Kosta Rika & 0.125 \\
\hline 28 & Djibouti & 0.233 & $\mathbf{6 0}$ & Kroasia & 0.125 \\
\hline 29 & Burkina Faso & 0.232 & $\mathbf{6 1}$ & Honduras & 0.125 \\
\hline 30 & Malawi & 0.221 & $\mathbf{6 2}$ & Georgia & 0.123 \\
\hline 31 & Rep Dominika & 0.213 & $\mathbf{6 3}$ & Turkmenista & 0.113 \\
& & & & $\mathrm{n}$ & \\
\hline 32 & Zambia & 0.210 & & & \\
\hline
\end{tabular}

\section{Sumber: Diolah oleh Penulis}

Sedangkan negara-negara sahabat yang dianggap sebagai 'teman biasa' dalam diplomasi ekonomi Indonesia (berdasarkan urutan 5 teratas) yakni: Tajikistan (0.112 poin), El Salvador (0.111 poin), Republik Kongo (0.102 poin), Lithuania (0.100 poin), dan Laos (0.099 poin). Indonesia telah menempatkan perwakilannya di beberapa negara sahabat kategori 'mitra biasa' ini seperti Laos, Bosnia Herzegovina, Fiji, Suriname, Vatikan, dan Noumea. Penempatan perwakilan Indonesia di negara-negara tersebut lebih pada pertimbangan politis dan sosial budaya seperti keterikatan sejarah seperti diaspora Indonesia, serta pertimbangan seperti sebagai sesama negara anggota ASEAN.

Tabel 9: Negara Sahabat Kategori Biasa Berdasarkan Indeks Diplomasi Ekonomi Tahun 2014

\begin{tabular}{|c|c|c|c|c|c|}
\hline Ranking & Negara & $\begin{array}{c}\text { Nilai } \\
\text { IDE }\end{array}$ & Ranking & Negara & $\begin{array}{c}\text { Nilai } \\
\text { IDE }\end{array}$ \\
\hline $\mathbf{1}$ & Tajikistan & 0.112 & $\mathbf{3 4}$ & Maladewa & 0.023 \\
\hline $\mathbf{2}$ & El Salvador & 0.111 & $\mathbf{3 5}$ & Islandia & 0.020 \\
\hline $\mathbf{3}$ & Kongo, Republik & 0.102 & $\mathbf{3 6}$ & Swaziland & 0.019 \\
\hline $\mathbf{4}$ & Lithuania & 0.100 & $\mathbf{3 7}$ & Kepulauan Marshall & 0.015 \\
\hline $\mathbf{5}$ & Laos & 0.099 & $\mathbf{3 8}$ & Guyana & 0.015 \\
\hline $\mathbf{6}$ & Sierra Leone & 0.098 & $\mathbf{3 9}$ & Montenegro & 0.014 \\
\hline $\mathbf{7}$ & Nikaragua & 0.097 & $\mathbf{4 0}$ & Suriname & 0.013 \\
\hline $\mathbf{8}$ & Eritrea & 0.091 & $\mathbf{4 1}$ & Kaledonia Baru & 0.013 \\
\hline $\mathbf{9}$ & Latvia & 0.090 & $\mathbf{4 2}$ & Uni Comoros & 0.011 \\
\hline $\mathbf{1 0}$ & Estonia & 0.085 & $\mathbf{4 3}$ & Barbados & 0.010 \\
\hline $\mathbf{1 1}$ & Kyrgyzstan & 0.079 & $\mathbf{4 4}$ & Malta & 0.009 \\
\hline $\mathbf{1 2}$ & Siprus & 0.078 & $\mathbf{4 5}$ & Cape Verde & 0.007 \\
\hline
\end{tabular}




\begin{tabular}{|l|c|c|c|c|c|}
\hline $\mathbf{1 3}$ & Liberia & 0.072 & $\mathbf{4 6}$ & Vanuatu & 0.006 \\
\hline $\mathbf{1 4}$ & Bosnia Herzegovina & 0.066 & $\mathbf{4 7}$ & Belize & 0.005 \\
\hline $\mathbf{1 5}$ & Afrika Tengah & 0.060 & $\mathbf{4 8}$ & Tonga & 0.004 \\
\hline $\mathbf{1 6}$ & Gambia & 0.055 & $\mathbf{4 9}$ & Antiqua \& Barbuda & 0.004 \\
\hline $\mathbf{1 7}$ & Albania & 0.053 & $\mathbf{5 0}$ & Sao Tome Dan Principe & 0.004 \\
\hline $\mathbf{1 8}$ & Gabon & 0.052 & $\mathbf{5 1}$ & Persemakmuran Dominika & 0.003 \\
\hline $\mathbf{1 9}$ & Mongolia & 0.052 & $\mathbf{5 2}$ & Saint Lucia & 0.003 \\
\hline $\mathbf{2 0}$ & Samoa & 0.052 & $\mathbf{5 3}$ & Grenada & 0.002 \\
\hline $\mathbf{2 1}$ & Moldova & 0.051 & $\mathbf{5 4}$ & Mikronesia & 0.002 \\
\hline $\mathbf{2 2}$ & Armenia & 0.050 & $\mathbf{5 5}$ & Saint Vincent and Grenadines & 0.001 \\
\hline $\mathbf{2 3}$ & Jamaika & 0.044 & $\mathbf{5 6}$ & Saint Kits and Nevis & 0.001 \\
\hline $\mathbf{2 4}$ & Namibia & 0.044 & $\mathbf{5 7}$ & Andorra & 0.001 \\
\hline $\mathbf{2 5}$ & Botswana & 0.040 & $\mathbf{5 8}$ & Zambia & 0.001 \\
\hline $\mathbf{2 6}$ & Makedonia & 0.038 & $\mathbf{5 9}$ & Palau & 0.001 \\
\hline $\mathbf{2 7}$ & Fiji & 0.031 & $\mathbf{6 0}$ & Palestina & 0.001 \\
\hline $\mathbf{2 8}$ & Lesotho & 0.028 & $\mathbf{6 1}$ & Monaco & 0.001 \\
\hline $\mathbf{2 9}$ & Trinidad \& Tobago & 0.027 & $\mathbf{6 2}$ & Liechsteinten & 0.000 \\
\hline $\mathbf{3 0}$ & Guinea Equatorial & 0.026 & $\mathbf{6 3}$ & San Marino & 0.000 \\
\hline $\mathbf{3 1}$ & Guinea-Bissau & 0.026 & $\mathbf{6 4}$ & Vatikan & 0.000 \\
\hline $\mathbf{3 2}$ & Bahama & 0.023 & $\mathbf{6 5}$ & Noumea & 0.000 \\
\hline $\mathbf{3 3}$ & Kepulauan Salomon & 0.023 & & & 0.000 \\
\hline
\end{tabular}

Sumber: Diolah oleh Penulis

\section{Kesimpulan dan Saran Kebijakan}

Diplomasi ekonomi kini menjadi salah satu prioritas dalam politik luar negeri Indonesia, namun hasil diplomasi ekonomi Indonesia seringkali dianggap belum optimal. Salah satu alasannya dikarenakan belum adanya sebuah blueprint atau grand design diplomasi ekonomi Indonesia sehingga saat ini arah dan pelaksanaan roda diplomasi ekonomi Indonesia serta negara-negara prioritas untuk kepentingan perekonomian dan diplomasi ekonomi Indonesia masih belum jelas serta terukur. Tulisan ini mencoba untuk menjawab salah satu tantangan diplomasi ekonomi Indonesia yakni penyusunan blueprint diplomasi ekonomi Indonesia.

Hasil IDE mengambarkan bahwa negara sahabat dengan nilai IDE tertinggi dan masuk dalam kategori negara strategis yaitu Tiongkok, 
Singapura, Malaysia, Amerika Serikat, dan Jepang. Banyak negara-negara di pasar nontradisional masuk dalam kategori negara strategis seperti Brazil, Meksiko, Turki, Polandia, dan hingga Pakistan, Bangladesh, Nigeria dan Iran yang turut masuk dalam kategori negara-negara mitra strategis. Hubungan diplomatik dengan beberapa negara strategis bagi diplomasi ekonomi Indonesia ini seperti Mauritius, Republik Demokratik Kongo, Angola, Ghana, dan Uganda masih dirangkap dari perwakilan Indonesia di negara sahabat lainnya. Sedangkan negara-negara kategori 'mitra biasa' seperti Laos, Bosnia Herzegovina, Fiji, Suriname, Vatikan, dan Noumea justru Pemerintah Indonesia menempatkan perwakilannya dengan pertimbangan politis dan sosial budaya seperti keterikatan sejarah seperti diaspora Indonesia, serta pertimbangan seperti sebagai sesama negara anggota ASEAN.

Jika penekanan hanya pada kepentingan diplomasi ekonomi semata, maka sepatutnya Pemerintah Indonesia membuka perwakilan di Mauritius, Republik Demokratik Kongo, Angola, Ghana, dan Uganda; dan menutup perwakilan di negara-negara seperti Laos, Bosnia Herzegovina, Fiji, Suriname, Vatikan, dan Noumea. Hasil IDE juga menyimpulkan bahwa negara-negara di pasar non-tradisional pada umumnya merupakan negara-negara strategis bagi kepentingan ekonomi Indonesia, namun negara-negara di pasar non-tradisional juga tak kalah penting dalam potensinya untuk turut mendukung pembangunan ekonomi Indonesia.

Tulisan ini hanya melihat IDE dengan data tahun 2014 saja sebagai rujukan guna melihat negara mana saja yang sepatutnya menjadi mitra strategis, mitra penting, serta 'mitra biasa' bagi kepentingan diplomasi ekonomi Indonesia. Rujukan ini setidaknya dapat menjadi catatan awal bagi Pemerintah Indonesia dalam memperkirakan negara-negara mana saja yang sepatutnya perlu mendapat perhatian dalam menjalankan diplomasi ekonomi Indonesia. Selain itu, IDE ini dapat menjadi sebuah embrio atau titik awal untuk mengajak dan mendorong para peneliti, akademisi, mahasiswa, serta praktisi yang tertarik untuk melakukan kajian IDE lanjutan dengan metode yang lebih sophisticated ke depannya dalam merumuskan sebuah grand design diplomasi ekonomi Indonesia ke depannya.

\section{Daftar Pustaka}

Badan Pengkajian dan Pengembangan Kebijakan (2014), “TTI Diplomacy: Kajian atas Kinerja Promosi Perdagangan, Investasi, dan Pariwisata Indonesia", Kementerian Luar Negeri Republik Indonesia, Jakarta.

Badan Pusat Statistik Republik Indonesia (2015), "Data Pariwisata: Jumlah Kedatangan Wisatawan Mancanegara ke Indonesia Menurut Negara Tempat Tinggal 2002-2014", Badan Pusat Statistik Online, Jakarta. Dapat diunduh pada situs:http://www.bps.go.id/linkTabelStat 
is/view/id/1388\#accordion-daftarsubjek2

Bank Indonesia (2015), "Remitansi Tenaga Kerja Indonesia Menurut Negara Penempatan",SitusBank Indonesia, Jakarta. Dapat diunduh pada situs: www.bi.go.id/seki/tabel/TABEL5_31.pd $\mathrm{f}$

Basri, F., \& Munandar, H., (2010), "Dasar-Dasar Ekonomi Internasional: Pengenalan dan Aplikasi Metode Kuantitatif", Kencana Prenada Media Group, Edisi Pertama, Jakarta.

Bayne, N., \& Woolcock, S., (2011), "The New Economic Diplomacy: Decision-Making and Negotiation in International Economic Relations", Global Finance Series, Ashgate, Third Edition, Surrey.

Fahmi, I., (2010), "Pengantar Politik Ekonomi”, Alfabeta, September, Edisi Pertama, Bandung.

Ismail, M., Santosa, D.B., \& Yustika, A.E., (2014), "Sistem Ekonomi Indonesia: Tafsiran Pancasila dan UUD 1945", Penerbit Erlangga, 15 Oktober, Malang.

Jemadu, A., (2015), "Diplomasi Ekonomi Indonesia: Menuju Solusi yang lebih Komprehensif', Jurnal Hubungan Luar Negeri, Edisi Januari-Juni, Vol. 30, No. 2, Kementerian Luar Negeri Republik Indonesia, Jakarta.

Kelana, I., (2015), "Tantangan Kemiskinan pada 2015", Republika Online, 2 Januari. Dapat diunduh pada situs: http://www.republika.co.id/berita/koran/ pareto/15/01/02/nhjny6-tantangankemiskinan-pada-2015

Kementerian Luar Negeri Republik Indonesia, (2015), "Rencana Strategis 2015-2019 Kementerian Luar Negeri Republik Indonesia", 6 April, Jakarta. Dapat diunduh pada situs: http://www.kemlu.go.id/Documents/RE
NSTRA_PK_LKJ/RENSTRA\%20KEM ENLU\%202015-

2019\%20FINAL\%20DONE\%20SK\%20

MENLU\%20pdf\%20version.pdf

Kementerian Perdagangan Republik Indonesia, (2015), "Neraca Perdagangan Indonesia - Total Periode 2010-2015", Jakarta. Dapat diunduh pada situs: http://www.kemendag.go.id/id/economic -profile/indonesia-export-

import/indonesia-trade-balance

Kementerian Perencanaan Pembangunan Nasional Republik Indonesia (2015), "Rancangan Akhir Rencana Pembangunan Jangka Menengah Nasional 2015-2019”, Buku I Agenda Pembangunan Nasional, Jakarta.

Kuncoro, M., (2013), "Mudah Memahami \& Menganalisis Indikator Ekonomi", UPP STIM YKPN, Yogyakarta, Maret, Edisi Pertama.

Perrotta, C., (2013), “Antonio's Serra Development Economics: Mercantilism, Backwardness, Dependence", History of Economic Thought and Policy. Dapat diunduh pada situs: http://www.francoangeli.it/riviste/Sched a_Rivista.aspx?IDArticolo=49477\&Tip $\mathrm{o}=$ ArticoloPDF

PricewaterhouseCoopers, (2013), "The World in 2050: Will the Shift in Global Economic Power Continue?", Februari, United Kingdom. Dapat diunduh pada situs: https://www.pwc.com/gx/en/issues/theeconomy/assets/world-in-2050-february2015.pdf

Pusat Pengkajian dan Pengembangan Kebijakan Kawasan Amerika dan Eropa, (2013), "Membangun Masa Depan Hubungan Indonesia dan Amerika Latin Melalui Peningkatan Kerjasama Perdagangan", Kementerian Luar Negeri Republik Indonesia, Desember, Jakarta. 
Putra, E.P., (2015), "Pemerintah Tambah 47 Negara Bebas Visa Indonesia", Republika Online, 1 September, Jakarta. Dapat diunduh pada situs: http://www.republika.co.id/berita/nasion al/umum/15/09/01/ntziag334-

pemerintah-tambah-47-negara-bebasvisa-indonesia

Saleh, S., (1986), Statistik Deskriptif. Yogyakarta: AMP YKPN.

Tambunan, T., (2001), "Perdagangan Internasional dan Neraca Pembayaran: Teori dan Temuan Empiris", LP3ES, Cetakan Pertama, Jakarta.

Wardhana, S., (2015), "Indonesia Remains Attractive for Investment", Tempo.Co, 25 Agustus, Jakarta. Dapat diunduh pada situs:

http://en.tempo.co/read/news/2015/08/2

5/056694861/Indonesia-Remains-

Attractive-for-Investment 